BEATA PURC-STĘPNIAK - GDAŃSK

\title{
MUZEUM NARODOWE W GDAŃSKU, JEGO GENEZA I FUNKCJA W STRUKTURZE I KULTURZE MIASTA
}

Muzeum Narodowe w Gdańsku jest jednym z najstarszych muzeów europejskich i doskonałym przykładem na połączenie walorów artystycznych z mi stycznymi, gdyż mieści się w malowniczym i położonym wśród zieleni pofranciszkańskim klasztorze. Sceneria wnętrza była i jest wykorzystywana przy tworzeniu ekspozycji, doborze wystawianych prac, a dzieła sztuki sakralnej uzyskują w nich odpowiednią oprawę. Jednak nie zawsze losy Muzeum pierwotnie Miejskiego, od 1950 r. Pomorskiego, a od 1972 r. Narodowego oraz przylegającego doń kościoła układały się pomyślnie w prawie 140-letniej historii muzealnictwa gdańskiego. Działalność tej placówki w praktyce pozwala śledzić historię muzeum, które poprzez wystawiane dzieła sztuki i swoją siedzibę związało się z losami Kościoła w Gdańsku.

Sprowadzony na początku XV w. Zakon Braci Mniejszych św. Franciszka z Asyżu w 1420 r. otrzymał parcelę budowlaną na Starym Przedmieściu, a w 1422 r. zostały sprecyzowane powinności fundacji ${ }^{1}$. Późnogotycki kościół pod wezwaniem Św. Trójcy był drugą co do wielkości świątynią po kościele NMP w Gdańsku. Jego prezbiterium wybudowano jako samodzielną budowlę pw. Wieczerzy Pańskiej. Ok. 1431 r. dobudowano do niej ukończoną w 1503 r. wielką halę kościoła Św. Trójcy, a od strony południowo-zachodniej kaplicę św. Anny ${ }^{2}$ na życzenie Kazimierza Jagiellończyka dla polskojęzycznych mieszkańców Gdańska i dlatego też zwaną ,,polnische Kirche”. Całość ukończono w 1514 r. Obok typowych zakonnych zajęć i prowadzenia szkół także dla mło-

${ }^{1}$ P. S i m s o n, Geschichte der Stadt Danzig, Bd IV, Urkunden, Danzig 1918, nr. 125, Bd. I, s. 169; S. F r ej li c h, Franciszkanie w Gdańsku, Kraków 1950, s. 14.

${ }^{2}$ Po 1496 r., a nie jak do tej pory przypuszczano ok. 1484 r. M. Ż y d o w i c z, Średniowieczna kaplica pw. św. Anny przy franciszkańskim kościele Św. Trójcy, „Acta Universitatis N. Copernici. Zabytkoznawstwo i Konserwatorstwo", 16 (1992) z. 225, s. 51. 
dzieży świeckiej franciszkanie zajmowali się pracami budowlanymi, uprawiali malarstwo, sztukę rzeźbiarską, złotniczą i snycerstwo ${ }^{3}$. Nowinki religijne wkrótce przyniosły zwiększenie liczby przychylnych luteranizmowi, a nawet sporadyczne akty niszczenia obrazów i krzyży. Dużą rolę odegrały w tym kazania wędrownego kaznodziei Jakuba Hegge. Zakonnicy zaczęli czuć się powoli zagrożeni w Gdańsku, ale na początku 1524 r. Rada Miasta powołała na kaznodzieję franciszkanina, doktora Aleksandra Svenichena. Był on prawdopodobnie zwolennikiem umiarkowanego luteranizmu i wygłaszał kazania w kościele Mariackim. Jednak postawa wyczekiwania i narastające niepokoje religijne oraz napięcia społeczno-polityczne dały znać o sobie. Zarządzono rewizję sreber i szat, a zakonników wezwano do publicznej dysputy z kaznodziejami. W 1525 r. doszło do zatargu w kościele Mariackim: doktorowi Svenichen, niejaki Eidten odmówił prawa głoszenia kazania, a incydent doprowadził do rewolty pospólstwa. W wyniku zaistniałych okoliczności Rada Miasta zmuszona była ustąpić i tak zadecydowano, by klasztor dominikanów zmienić na szpital, a klasztor franciszkanów na szkołę. Natomiast mnisi mieli przejść do klasztoru karmelitów. Jednak Zygmunt I Stary nakazał miastu (Statuty Zygmuntowskie) powrócić do dawnego kultu. Przywódcy rewolty ratowali się ucieczką lub zostali uwięzieni. Restytuowano także zakonników franciszkańskich ${ }^{4}$. W 1555 r. nastąpiła jednak kasacja klasztoru, a jego budynki z powodu narastającej fali protestantyzmu przejęły władze miasta ${ }^{5}$. W 1570 r. pozbyto się ostatnich zakonników. Franciszkanie powrócili do Gdańska dopiero w kwietniu 1945 r. W pofranciszkańskim klasztorze od 1558 r. znalazło schronienie gimnazjum protestanckie (studium particulare) przekształcone z czasem (po reformach Jakuba Fabriciusa) w wyżej zorganizowaną szkołę średnią, a ok. 1643 r. w słynne Gimnazjum Akademickie (zwane też Athenae Gedanensis), posiadające wielki księgozbiór, zbiór okazów przyrodniczych, monet, w tym antycznych, medali, portretów, instrumentów muzycznych i astronomicznych oraz innych przedmiotów naukowych ${ }^{6}$. Podstawę tego zbioru zapewniła biblioteka

${ }^{3}$ Z. M a s s o w a, Das Franziskanerkloster und Nationalmuseum zu Danzig, w: Klöster und Moonaastische Kultur in Hansestädten, Beiträge des 4. Wissenschaftlichen Kolloquiums Stralsund, 12 bis 15 Dezember 2001, Stralsunder Beiträge, red. C. Kimminus-Schneider, M. Schneider, Rahden/Westf. 2003, s. 225-238, s. 226.

${ }^{4}$ K. C i e śl a k, Między Rzymem, Wittemberga a Genewa. Sztuka Gdańska jako miasta podzielonego wyznaniowo, Wrocław 2000, s. 53-54.

${ }^{5}$ Historia Gdańska, red. E. Cieślak, t. 2, Gdańsk 1982, s. 223; M. B o g u c k a, Luter a Gdańsk. Społeczne przesłanki zwycięstwa luteranizmu w Gdańsku w XVI wieku, „Rocznik Gdański”, 43 (1983) z. 1, s. 55; K. C i e ś la k, Między Rzymem, s. 45

${ }^{6}$ Podstawę księgozbioru stanowiła darowizna włoskiego humanisty Giovanniego Bernarda Bonifacio markiza d'Ori, który w zamian za dożywotnią opiekę podarował miastu swój liczący 1000 tomów księgozbiór. W chwili otwarcia biblioteka liczyła 4000 ksiąg. Wygląd biblioteki (dzieło Reinholda Curckego) w 2 poł. XVII w. ukazuje miedzioryt wg. Andreasa Stecha. Zbiory były cały czas uzupełniane poprzez darowizny. W 1817 r. księgozbiór liczył 26 tysięcy woluminów. W 1900 r. wzniesiono gmach biblioteki przy ulicy Wałowej w Gdańsku. W opublikowanej w 1677 r. rozprawie Samuela Schelwiga profesora gimnazjum, siedzibę szkoły nazwano „przybytkiem muz", gdyż muzy inspirowały uczonych i uczniów, ale także księgi jak muzy okazywały się poży- 
franciszkanów ${ }^{7}$. Od 1560 r. kościół Św. Trójcy był kościołem szkoły i miejscem głoszenia kazań profesorów teologii i rektorów gimnazjum nie tylko luteran, ale i duchownych z kalwińskiego kościoła św. Piotra i Pawła. Pofranciszkański kościół był placem walki dwu wyznań. W gimnazjum nauczano od 1589 r. języka polskiego, a także zorganizowano małe audytorium anatomiczne. Pierwszy pokaz anatomiczny przeprowadzony był przez Joachima Oelhafa w $1613 \mathrm{r}$. Tu uczyli się Aegidius Strauch, Abraham Calov, August Bertling, Jan Adam Kulmus, Michał Krzysztof Hanow, Gottfried Lengnich i poeta Andreas Gryphius ${ }^{8}$. W czasie tzw. drugiej reformacji na przełomie XVI i XVII wieku wielki wpływ w gimnazjum miał kalwinizm, a szkoła stanowiła wybitny ośrodek myśli protestanckiej i przetrwała do pocz. XIX w. Wycofująca się armia napoleońska zdewastowała budynki, a pruskie władze wojskowe w 1814 r. urządziły w dawnym klasztorze szpital garnizonowy i skład broni. Zbudowano jednak dla szpitala nowe lokum i dawny klasztor popadłby w ruinę, gdyby nie starania wrocławianina z pochodzenia, Rudolfa Freitaga, wykładowcy Królewskiej Szkoły Sztuk Pięknych w Gdańsku, wielbiciela antyku i znawcy sztuki włoskiej, który uzyskał od władz wojskowych w marcu 1848 r. zezwolenie na zamieszkanie w klasztorze oraz zbudowanie tam swej pracowni rzeźbiarskiej. Artysta miał zbiór pamiątek z przeszłości i dużą ilość odlewów gipsowych, a także uzyskał zgodę na zorganizowanie ich ekspozycji. Freitag marzył, by było to muzeum sztuki. Jemu też budynek klasztoru zawdzięcza tak naprawdę swe istnienie, gdyż w międzyczasie władze wojskowe chciały gmach przebudować na koszary ${ }^{9}$, Pruskie Ministerstwo Wyznań Religijnych na więzienie, a władze miejskie na szkołę. Do czasów adaptacji na muzeum sam gmach klasztorny również ulegał zmianie: wyburzono od strony południowej budynek kuchni i przylegające do klasztoru domy szkieletowe widoczne na starych rycinach. Wygląd południowego skrzydła budowli zachowała akwarela Bocka, a skrzydło północne znamy z obrazu Ottona Brauswettera, który w 1861 roku przedstawił na nim Freitaga. Rzeźbiarz zaprzyjaźnionemu pastorowi pokazuje właśnie zabudowania klasztorne. Na obrazie autorstwa Augusta Stryowskiego, Rudolf Freitag namalowany został w jednym z pomieszczeń klasztoru zaadoptowanym na pracownie rzeźbiarską. Czteroskrzydłowy gotycki klasztor założony

teczne dla ich umysłów. S. S c h e 1 w i g, O poczatkach Biblioteki Gdańskiej. List i rozprawa, opr. Z. L. Pszczółkowska, Gdańsk 1992; B. J a k u b ow s k a, Ostatnia bomba na muzeum, „30 dni”, 15 (2000) z. 1, s. 37; Danzig sein Platz in Vergangenheit und Gegenwart Hrgs, red. A. von Udo, Warschau-Lüneburg 1998, s. 454.

${ }^{7}$ Ostatni kustosz franciszkański Johann Rollau przekazał bibliotekę Radzie Miasta. Księgozbiór liczył 1057 rękopisów i ksiąg. W 1558 r. został on przekazany gdańskiemu gimnazjum. Do tego doszedł księgozbiór markiza d'Ori (1140), a w 1597 r. Rada Miejska za sumę 1530 marek powiększyła biblioteczne zasoby. H. S i e g l e r, Danzig erleben. Ein kulturhistorischer Reisebegleiter durch Gdańsk, Düsseldorf 1985, s. 44.

${ }^{8}$ Stownik Biograficzny Pomorza Nadwiślańskiego, red. Z. Nowak, t. 2, Gdańsk 1994, s. 190191.

${ }^{9}$ T. P i a s k o w s k i, Dzieje przebudowy średniowiecznego klasztoru pofranciszkańskiego na siedzibę pierwszego muzeum w Gdańsku, „Jantarowe Szlaki”, 37 (1994) nr 3 (233), s. 24-27. 
był na planie zbliżonym do kwadratu $\mathrm{z}$ wirydarzem pośrodku. Imponującą była elewacja wschodnia skrzydła południowego. Pojęcie o wyglądzie starego klasztoru daje przyziemie, w którym w krużgankach, refektarzach i furtach znajdują się pochodzące z ok. 1503-1514 r. sklepienia kryształowe, gwiaździste i siatkowe. To one powodują odczuwany przez zwiedzających do dziś, niezapomniany nastrój wiecznej adoracji i kontemplacyjnego majestatycznego spokoju.

Powstanie Muzeum Miejskiego w Gdańsku (Stadtmuseum) wiązało się z silną potrzebą służenia miastu i uświadomienia sobie konieczności otoczenia opieką zgromadzonych w nim przez pokolenia miłośników sztuki kolekcji i artystycznych zbiorów. Ten narastający w XIX w. prąd świadomego zainteresowania społeczeństwa ideą powoływania do życia instytucji o charakterze otwartym, zabezpieczał spuściznę kulturalną oraz gwarantował duchowy rozwój przez organizowanie wystaw i rozszerzanie zasobów o nowe nabytki. Wiara w jedność i postęp świata oraz optymistyczny idealizm filozoficzny nakazywały gromadzić dorobek artystyczny utrwalający nieprzemijające wartości. Tym bardziej, że zdawano sobie sprawę, iż czasy dawnej świetności Gdańsk ma za sobą. Wśród rodzajów sztuk ceniono najbardziej malarstwo i grafikę, ale kryteria oceny dawnej sztuki wraz z przemianami społecznymi również zmieniały się. Chodziło o zainteresowania nie tylko tym, co było od dawna uświęcone i wartościowe, lecz o udokumentowanie w duchu monograficznym i rzeczowym wielu dziedzin kultury. $Z$ jednej strony wypływało to z lokalnego patriotyzmu, często nastawionego na gromadzenie w tradycyjnym eklektyczno - historycznym tonie, ale także dopasowanie się do nowych idei muzealniczych, docierających z Europy, dotyczących powstawania nowych typów muzeów i nowej architektury muzealnej (dokonania Gottfrieda Sempera, wystawa w 1851 r. w Londynie w Pałacu Kryształowym, wzory muzeów specjalistycznych w Anglii i krajach niemieckiego obszaru językowego oraz $\mathrm{w}$ Ameryce $)^{10}$. Te rozterki czasu przejściowego osadzonego między dwoma epokami wiązały się z marzeniami o powrocie do tego, co minęło, a także związania chlubnej przeszłości z teraźniejszością. Stosunek do przeszłości nasycony na początku XIX w. duchem romantyzmu dla wykształconej elity gdańszczan zrodził zamysł o powstaniu muzeum typu artystycznego. Również myśl stworzenia muzeum, zwłaszcza po okresie wojen napoleońskich, podczas których dochodziło do bezprawnych grabieży dzieł sztuki i wywożenia ich, była podparta chęcią stworzenia zbioru, który byłby symboliczny i naturalny dla Gdańska. Oprócz wartości naukowych niósłby moralne i zaświadczał o potędze miasta oraz jego mieszkańców. Zwłaszcza wywiezienie Sądu Ostatecznego Memlinga wywołało oburzenie i protesty. Coraz więcej kolekcjonerów i zbieraczy pragnęło uchronić swą spuściznę i przekazać ją miastu w nadziei ocalenia. Wśród gdańskich miłośników, mecenasów sztuki i kolekcjonerów najwięcej ofiarodawców zyskiwała Biblioteka Rady Miejskiej Gdańska (Bibliotheca Senatus Gedanensis) ${ }^{11}$. Miasto było znanym ośrodkiem transmisyjnym sztuki (nie tylko w sensie samej produkcji), przez

${ }^{10}$ Z. Ży g u ls k i, Muzea na świecie, Warszawa 1982.

${ }^{11}$ P. G r o t h, Zbiór obrazów Biblioteki Gdańskiej Polskiej Akademii Nauk, , Libri Gedanenses”, 4-5 (1973) s. 79-91; A. M o s in g i e w i c z, Jan Adam Kalamus i jego portret w bibliotece gdań- 
Gdańsk sprowadzano europejskie nowinki od luster weneckich, tapiserii, porcelany, sreber, mebli, książek po wyrafinowane dzieła sztuki ${ }^{12}$. Tą drogą między innymi przybywały też dla szlachty, królów polskich obrazy, rzeźby i grafiki, wyroby rzemiosła artystycznego ${ }^{13}$. W Gdańsku wielu bogatych mieszczan amatorsko zajmowało się sztuką ${ }^{14}$, należeli do nich między innymi: Schwarzwaldowie, Uphagenowie. Także artyści zbierali dzieła sztuki między innymi: Jacob Wessel, Friedrich Anton Lohrmann, Mateusz Deisch, Friedrich Wilhelm Du But, Joergen Martin Steunetz. Istniał także szereg mniej znanych zbieraczy sztuki. ${ }^{15}$ Sławne XVIII-wieczne biblioteki naukowe, galerie obrazów, zbiory rysunków i rycin np. Albrechta i Wilhelma Heinricha, Gotfrieda Schwartza, Franciszka Gotfryda Rottenburga ${ }^{16}$, Fryderyka Muhla ${ }^{17}$ zostały rozproszone, sprzedane przypadkowym nabywcom lub zakupione przez innych kolekcjonerów na aukcjach zagranicą i w sa mym Gdańsku ${ }^{18}$, albo tak jak zbiory Schopenhauerów wywiezione do nowego

skiej Polskiej Akademii Nauk. Nowy człowiek w starych ramach, „Libri Gedanenses”, 11-12 (1994) s. 47-77; T e n ż e, Portret Jakuba von Eggersa przyczynek do twórczości Jakuba Wessla, „Gdańskie Studia Muzealne", 6 (1995) s. 23-44; H. K o w a 1 s k a, Uwagi na marginesie eseju o kolekcjonerstwie gdańskim, „Porta Aurea. Rocznik Zakładu Historii Sztuki Uniwersytetu Gdańskiego”, 6 (1999) s. 153-160; M. B o g u c k a, Die Kunstsammlungen in Danzig in der ersten Hälfte des 17. Jahrhunderts als soziologische und psychologische Erscheinung, w: Kopet uns werk by tyden. Beiträge zur hansischen und preußischen Geschichte. Festschrift für Walter Stark zum 75. Geburtstag / Hrsg, red. N. Jörn. Schwerin 1999, s. 245-250; A. R. C h o d y ń s k i, Kolekcjonerstwo, w: Aurea Porta Rzeczypospolitej. Sztuka Gdańska od połowy XV do końca XVIII wieku, t. 1, Gdańsk 1997, 349-363; Te n ż e, Zbiory dziet sztuki i galerie malarstwa w Gdańsku u schytku XVII w. i XVIII w., „Gdańskie Studia Muzealne", 6 (1995), s. 76.

${ }^{12}$ E. C i e ś 1 a k, Historia Gdańska, t. 3, Gdańsk 1993, s. 60, 82, 602; A. Mo r a w iń s k a, Kolekcjonerstwo polskie i Anglia w dobie Oświecenia, w: Polska i Anglia, Stosunki kulturalno-artystyczne, Warszawa 1974; Z. Wa ź b i ń s k i, Muzeum i zbiory artystyczne epoki nowożytnej. Wiek XVII i XVIII, cz. 2, Toruń 1988, s. 90; A. R. C hod yń s k i, Kolekcjonerzy i kolekcje w Gdańsku XVIXIX wieku (do 1872 roku). Inventarium et taxam dziet sztuki, „Rocznik Historii Sztuki”, 27 (2002) s. 171-210, 206.

${ }^{13}$ Arrasy na dwór królewski w Krakowie, serie tapiserii dla Zygmunta III Wazy, sprawa arrasów ukrytych w Gdańsku dla Jana Kazimierza. Zob. R. S z m i t k i, Wyprzedaż mienia po Janie Kazimierzu w roku 1673, Warszawa 1995, s. 49. Zachowała się korespondencja między Radą Miasta Gdańska a królem Stanisławem Augustem Poniatowskim na temat sprowadzanych do jego zbiorów przez Gdańsk miedziorytów. Zob. A. R. C h o d y ń s k i, Kolekcjonerzy i kolekcje, s. 176, 204-207, 210.

${ }^{14} \mathrm{~J} . \mathrm{B}$ e r n o u 11 i, Reisen durch Brandenburg, Pommern, Preußen, Curland, Russland und Polen in den Jahren 1777 und 1778, Bd. 1, Reise nach Danzig und Beschreibung der Merkwürdigkeiten diese Stadt, Leipzig 1779, s. 259-263, 312.

${ }^{15}$ A. R. C h o d y ń s k i, Kolekcjonerzy i kolekcje, s. 195-200.

${ }^{16}$ F. G. H ir s c h in g, Nachrichten von Gemäldsammlungen, t. 2, Erlangen 1786.

${ }^{17}$ J. M u h 1, Die Gemälde - und Stichsammlung der Familie Muhl in Danzig, „Mitteilungen des Westpreußischen Geschichte Vereins“, 11 (1912), heft 4, s. 65-69.

${ }^{18} \mathrm{~A}$. R. C h o d y ń s k i, Kolekcjonerstwo gdańskie w XIX w. a zbiory muzealne, w: Zeszyty Muzeum Pomorskiego w Gdańsku, Gdańsk 1971, s. 59-77; D. C h o d o w i e c k i, Künstlerfahrt nach Danzig im Jahre 1773. Das Künstler Tagebuch dieser Reise in deutscher Übertragung und Skizzenbuch in getreuer Nachbildung mit seiner Einleitung, red. H. von Francke, Leipzig-Berlin 1919, s. 9; 
miejsca zamieszkania - Hamburga ${ }^{19}$. Bądź też dramatycznie stracone przez utratę prestiżu i bankructwo, jak w przypadku burmistrza Gotthilfa Wernicka (1720$1773)^{20}$. Lukę kulturalną i potrzebę obcowania ze sztuką należało zapełnić i taką pró bę podjął Jacob Kabrun (Cockborn) (1759-1814), dążąc do utworzenia w Gdańsku instytutu sztuk wyzwolonych, instytucji kształcącej młodzież w zakresie sztuk pięknych. W końcu utworzona przez Jakuba Kabruna biblioteka, galeria obrazów, kolekcja rysunków i rycin legatem z $1814 \mathrm{r}^{21}{ }^{21}$ została przekazana miastu już z myślą o udostępnianiu zbiorów ${ }^{22}$. Ponadto Kabrun przeznaczył 100 tys. zł na wydatki związane $\mathrm{z}$ założeniem i funkcjonowaniem instytutu naukowego dla dobra miasta. Włączenie Gdańska do państwa pruskiego, świadomość ważnej roli, jaką pełnił w przeszłości i opuszczenie po dużych zniszczeniach w sferze materialnej, kulturalnej i artystycznej było na pewno znaczącym argumentem do utworzenia muzeum w Gdańsku. Taka instytucja stanowiła ważny element intelektualnego wizerunku życia miasta i dowód na podniesienie jego prestiżu i rangi.

W kulturze artystycznej XIX w. przywracanie dawnej świetności zabytkom było zajęciem preferowanym, podobnie jak myśl o ich godnej prezentacji ${ }^{23}$. Możemy więc powiedzieć, że gdańska epoka kolekcjonerstwa ${ }^{24}$, która przecież

D. C h o d o w i e c k i, Reise von Berlin nach Danzig im Jahre 1773. Daniela Chodowieckiego podróż z Berlina do Gdańska w 1773 roku, Berlin 2000; Zob. też: Daniela Chodowieckiego dziennik z podróży do Gdańska z 1773, oprac. M. Paszylka, Gdańsk 2002; J. T a 1 b i e r s k a, Grafika-artyści, odbiorcy, tematy, w: Aurea Porta, t. 1, s. 183-203; A. M o s in g i e w i c z, Portret Jakuba von Eggersa. przyczynek do twórczości Jakuba Wessla, „Gdańskie Studia Muzealne”, 6 (1995) s. 23-44; T. Gr z y b o w s k a, A. M o s in g i e w i c z, Ilustracja naukowa, w: Aurea Porta, s. 204-215; H. K o w a $1 \mathrm{~s} \mathrm{k}$ a, Uwagi na marginesie eseju o kolekcjonerstwie gdańskim, „Porta Aurea. Rocznik Zakładu Historii Sztuki Uniwersytetu Gdańskiego", 6 (1999) s. 153-160.

${ }^{19}$ A. R. C h o d y ń s k i, Kolekcjonerzy i kolekcje, s. 189-190.

${ }^{20}$ Tamże, s. 179.

${ }^{21}$ Testament des am 25 Oct. 1814 verstorbenen Kaufmann Jacob Kabrun, „,Der Neuen Preussischen Provinzial-Blättern“, 9 (1856) s. 210-212; O. V ö 1 k e 1, Jakob Kabrun und die Gründung und Entwicklung der Handels-Academie, w: Festschrift zur Erinnerung an des Fünfzigjährige Bestehen der Danziger Handels-Academie (Kabrun 'sche Stiftung), Danzig 1882, s. 13.

${ }^{22}$ Straty wojenne. Kolekcja Jacoba Kabruna, t. 1, Ryciny. Historia i dokumentacja, t. 2, Ryciny. Katalog, t. 3, Ryciny, Ilustracje, oprac. K. Zabuska, red. J. Talbierska, Poznań 2000; H. K o w a 1 s k a , Powstanie i działalność Towarzystwa Sztuk Pięknych w Gdańsku w świetle statutu, w: $Z$ dziejów kultury Pomorza XVIII-XIX wieku. Materiały z seminarium. Uniwersytet Gdański, 26 X.1999, red. J. Borzyszkowski, Gdańsk 2002, s.67.

${ }^{23}$ Już od XVII wieku na dobre interesowano się przeszłością Gdańska wydając zbiory ilustrujące widoki miasta i jego opisy oraz opisy stanu zachowania zabytków. A. R. C h o d y ń s k i, Początki Muzeum Pomorskiego w Gdańsku, „Zeszyty Muzeum Pomorskiego”, 1970, s. 52-57; Działało w mieście Towarzystwo Ochrony Pomników Sztuki (Verein zur Erhaltung der Kunstdenkmäler in Danzig oraz Verein zur Erhaltung der alterthümlichen Bauwerke und Kunstdenkmäler Danzigs). A. R. C h o d y ń s k i, Malarz gdański -Wilhelm August Stryowski (1834-1917), „Rocznik Gdański”, 36 (1976), s. 137-159, s. 145. J. F r y c z, Restauracja i konserwacja zabytków architektury w Polsce w latach 1795-1918, Warszawa 1975.

${ }^{24}$ P. S i m s o n, Der Arturshof in Danzig und seine Brüderschaften, die Banken, Danzig 1900; 
nadal rozwijała się $\mathrm{w}$ XIX $\mathrm{w}^{25}$, ale była uwarunkowana w przeważającej mierze dobrobytem mieszkańców, a nie wyłącznie kryteriami estetycznymi ${ }^{26}$ została zamknięta w 1872 r. utworzeniem Stadtmuseum Danzig ${ }^{27}$ - pierwszego muzeum o charakterze instytucjonalnym, którego działalność kontynuuje obecnie Muzeum Narodowe w Gdańsku. Jego początki poprzedziło powołanie w 1804 Szkoły Sztuk Pięknych, a następnie w 1835 r. założenie Kunstverein (Towarzystwa Sztuk Pięknych), którego założyciele m. in. John Simpson mieli świadomość konieczności powołania muzeum i promowania artystów ${ }^{28}$. Funkcjonowanie tych dwóch instytucji wprowadziło w kupieckim Gdańsku programy edukacyjne, wystawiennicze i przekaz wiedzy o sztuce (odczyty i wykłady), które świadczą o wysokiej estetyzacji życia codziennego ${ }^{29}$. Kolekcja podarowana przez Jacoba Kabruna miastu w 1814 r. została przeniesiona w 1817 r. do Resursy Kupieckiej

G. C 1 u n y, Danzigs Kunst und Kultur im 16. und 17. Jahrhundert, Frankfurt a/Main 1910; P. S i m s o n, Geschichte der Stadt Danzig, Bd 2, 3, 4, Danzig 1918-24; N. von H o 1 s t, Danziger Kunstkabinette und Kunsthandelbeziehungen im 18 Jahrhundert, „Mitteilungen des Westpreußischen Geschichtsts - Vereins“, 22 (1934) Heft 3, s. 59-69; G. C 1 u n y, Kunsthandel, Gemäldesammlung und ihr Schicksal um 1750-1850 in Danzig, „Weichselland“, 38 (1939) Heft 1, s. 17-22; I. R e m b o w s k a, Dom bogatego mieszczanina gdańskiego w II poł. XVII i XVIII wieku, Gdańsk 1979, s. 112-126; A. R. Ch od yń s k i, Kolekcjonerstwo, w: Aurea Porta Rzeczypospolitej, t.1, s. 186362.

${ }^{25}$ Do zbieraczy gdańskich należał: Gustaw Adolf Fischer, tajny radca Pott, Daniel Eggebert, Franz Massias, Rolle du Rosey, Paunenburg, Lesser Giełdziński i Stryowski, Heinich A. Kupferschmidt, Wuertemberg: A. R. C h o d yń s k i, Początki Muzeum Pomorskiego w Gdańsku, „Zeszyty Muzeum Pomorskiego", 1970, s. 60- 64; H. K o w a 1 s k a, Uwagi na marginesie eseju o kolekcjonerstwie gdańskim, „Porta Aurea. Rocznik Zakładu Historii Sztuki Uniwersytetu Gdańskiego”, 6 (1999), s. 153-160.

${ }^{26}$ Już na początku lat 20 XIX w. Adam Breysig organizował niewielkie wystawy malarstwa np. Johanna Carla Schultza w Ratuszu Głównego Miasta. H. K o w a $1 \mathrm{~s} \mathrm{k} \mathrm{a,} \mathrm{Powstanie} \mathrm{i} \mathrm{działalność}$ Towarzystwa Sztuk Pięknych, s. 67.

${ }^{27}$ A. Chodyń s ki, Początki Muzeum Pomorskiego w Gdańsku, „Zeszyty Muzeum Pomorskiego", 1970, wyd. 1971.

${ }^{28}$ H. B. M e y e r, Hundert Jahre Kunstverein zu Danzig, Danzig 1935; Historia Gdańska, t. 4, cz. 1: 1815-1920, red. E. Cieślak, Sopot 1997; Pierwszymi organizatorami Kunstverein byli: Johann Carl Schultz (1801-1873)- artysta malarz, profesor gdańskiej Szkoły Sztuk Pięknych, John Simpson (1786-1857) kupiec oraz Friedrich Engelhardt (1793-1880) - dyrektor Gimnazjum Miejskiego. Wystawy urządzano co dwa lata w Bramie Zielonej. Obecnie do tej tradycji wystawienniczej powrócono, oddając w 2004 r. Muzeum Narodowemu w Gdańsku ten gmach jako jeden z oddziałów. K o w a 1 s k a, Powstanie i działalność Towarzystwa Sztuk Pięknych, s. 65-80.

${ }^{29}$ Tym bardziej, że na organizowanych przez Towarzystwo wystawach, kupowano nowe obrazy z myślą oddania ich dla przyszłego muzeum. Verzeichniss der Gemälde und Kunstsachen der dritten Ausstellung des Kunst-Vereins zu Danzig, Danzig 1838. H. K o w a $1 \mathrm{sk}$ a, Martwe natury w XIX-wiecznych zbiorach gdańskich kolekcjonerów, „Sztuka i kultura”, 3 (2002), s. 193-202, 200. Wystawiano także do poł. XIX w. rzemiosło artystyczne. Recenzje były zamieszczane w: Danziger Dampfboot i Danziger Intelligenzblatt; H. B. M e y e r, Hundert Jahre Kunstverein zu Danzig 18351935, Danzig 1935. Wykłady odbywały się w restauracjach i kończyły się kolacją w restauracji przy ul. Ogarnej 96. Cz. B e tl e j e w s k a, Muzeum Miejskie w Gdańsku w latach 1870-1945, w: Straty 
concordia i oddana pod konserwatorską opiekę Johanna Adama Breysiga (1766-1831), malarza a zarazem dyrektora Gdańskiej Szkoły Sztuk Pięknych ${ }^{30}$. W 1820 r. odbyła się pierwsza publiczna ekspozycja zbiorów w kamienicy Eggera i Normana przy ul. Długi Targ. Czas jej prezentacji trwał do 1822 r., a między rokiem 1832 a 1833 zmieniano jej miejsce wielokrotnie: $m$. in. w nowo wówczas powołanym Instytucie Handlowym w kamienicy przy Dworze Artusa (dzisiejszy Dom Ekonomistów), lub w Stadtmillerische Haus przy ul. Ogranej 80. To ostanie miejsce bez zamian utrzymało się, aż do czasu powołania Stadtmuseum w 1872 r. i przeniesienia całości funkcjonującej pod nazwą Kabrun'sche Bildgallerie i Kabrun'sche Stiftung ${ }^{31}$ do dawnego klasztoru franciszkanów, siedziby Gimnazjum Akademickiego. Władze Gdańska złożyły kabrunowską kolekcję w klasztorze w październiku 1872 r. Natomiast warunki formalnego jej przekazania określała umowa z 6 kwietnia 1875 r., ponieważ prawnym opiekunem kolekcji była Kupiecka Rada Starszych. O stanie zbiorów dowiadujemy się z dokonywanej w tamtych czasach dokumentacji rysunków i rycin opublikowanych następnie w 1861 r., w katalogu Blocka-Duisburga ${ }^{32}$ oraz w spisie obrazów należących do kolekcji malarstwa Jacoba Kabruna oraz do kolekcji jego syna Augusta ${ }^{33}$, które stanowią do chwili obecnej pokaźną część działów: malarstwa, rysunku i grafiki muzeum $^{34}$.

Wypowiedzi z roku 1845 i 1847 Rudolfa Freitaga (1805-1890)- rzeźbiarza i profesora Szkoły Sztuk Pięknych w Gdańsku, który poświęcił się organizacji muzeum świadczyły o determinacji powołania do życia muzeum i traktowania go jako źródła dydaktycznego zarówno w procesie artystycznego kształcenia, jak również jako miejsca przechowywania pamiątek przeszłości ${ }^{35}$. Finansowe wsparcie dla utworzenia muzeum oraz zorganizowanie funduszu na zakupu dzieł sztuki, pensje kustoszy i administracji dał kupiec Carl Gottfried Klose, który zapisał w testamencie na ten cel 64000 talarów, a jego spadkobiercy wypłacili sumę 60.000 talarów. Formalne powołanie instytucji nastąpiło 30 marca 1870 r. Muzeum miało nosić nazwę: Danziger Stadt-museum gegründet von Carl Gottfried Klose

wojenne Muzeum Miejskiego w Gdańsku, t.1, Gdańsk, s. 10, 18. Archiwum Państwowe w Gdańsku [APG], sygn. APG, 361/189.

${ }^{30} \mathrm{C}$ h o d y ń s ki, Poczatki Muzeum Pomorskiego, s.71.

${ }^{31}$ G. Z i n ó w k o, Zbiory rysunków w Muzeum Miejskim (Stadtmuseum) w Gdańsku, w: Straty wojenne Muzeum Miejskiego w Gdańsku. Straty w dziedzinie sztuki: malarstwa, rysunku, grafiki, rzeźby, t. 1, Gdańsk 2005, s. 111.

32 J. C. B 1 o c k, C.G. von D u is bu rg, Catalog einer Sammlung von Kupferstichen, Holzschnitten, Litographien und Handzeichnungen, welche von dem Anno 1814 hier verstorben Herrn Jacob Kabrun der Kaufmanschaft hierselbst hinterlassen worden sind, Danzig 1861.

${ }^{33}$ Die Städtischen Sammlung mit Einschluss der dem Stadtmuseum übereigneten Sammlungen des Kunstvereins zu Danzig und des Freulein Louise Wilhelmine Trauschke, Biblioteka MNG, rękopis, syg. 1914.

${ }^{34} \mathrm{~K} . \mathrm{Z}$ a b u s k a, Kolekcja kupca Jakuba Kabruna wzbiorach Muzeum Narodowego w Gdańsku, „Porta Aurea. Rocznik Zakładu Historii Sztuki Uniwersytetu Gdańskiego”, 3 (1994) s. 75-90.

${ }^{35}$ W. D r o s t, Die Gründung des Danziger Stadtmuseums durch Rudolph Freitag (1805-1890), w: Westpreussen Jahrbuh, Bd. 30 Münster 1980, s. 99-100. 
und seinen Erben. Nadzór nad Stadtmuseum objął magistrat miasta Gdańska i dwunastoosobowe kuratorium wybierane co cztery lata. Należeli do niego nadburmistrz miasta, trzej radni oraz osiem osób z Towarzystwa Sztuk Pięknych ${ }^{36}$. Pierwszym kustoszem Stadtmuseum został Freitag ${ }^{37}$, który od 1848 r. otrzymał prawo zamieszkania w klasztorze i do $1890 \mathrm{r}$. wytrwale mimo, że nie otrzymywał środków finansowych pozyskiwał wiele obiektów i dbał o remont, przysposabiający mury klasztoru do nowych wystawienniczych celów. Przejęcie budynków od władz wojskowych nastąpiło w $1855 \mathrm{r}$.

Prace remontowe prowadzone były w dawnym klasztorze franciszkanów od roku 1867 do końca 1872 przez władze miasta według projektów modernizacyjnych inżyniera budowlanego Juliusa Alberta Lichta $(1821-1898)^{38}$. Budynek klasztorny jednak nie był w całości przeznaczony na muzeum. Wiele lat trwał spór między Freitagiem a Lichtem i władzami miasta o zasady konserwatorskie (zachowawcza konserwacja czy eklektyczno-romantyczna), o to jak powinien wyglądać budynek po remoncie i czy słusznym jest łączenie w nim dwu funkcji - muzealnej i szkolnej (Provinzial-Gewerbeschule oraz Königliche Kunst und Gewerkschule) $)^{39}$. Część pomieszczeń bowiem miała być użytkowana przez wyższe gimnazjum św. Jana (miało się mieścić na I piętrze w skrzydle wschodnim i południowym), a tyko krużganki, skrzydło zachodnie i poddasze miało otrzymać muzeum miejskie. Kustoszowi muzeum przysługiwało bezpłatne mieszkanie. Wszystko zostało szczegółowo opisane w zawartej umowie ${ }^{40}$. W każdą niedzielę i przynajmniej raz w tygodniu wstęp dla zwiedzających miał być wolny. Kopie i studia z natury mogły być robione nieodpłatnie. Regulamin zwiedzania z 1874 r. mówił o bezpłatnych niedzielach i środach od godz. 11 do 14. Pierwszą muzealną wystawę otwarto w grudniu 1872 r., a w roku następnym, w sali wielkiego refektarza Orkiestra Gdańskiego Towarzystwa Muzycznego dała swój koncert ${ }^{41}$. W listopadzie 1872 r. muzeum podpisało umowę z Kunstverein dotyczącą użyt-

${ }^{36}$ Cz. B e t l e j e w s k a, Muzeum Miejskie w Gdańsku, s. 13-15.

${ }^{37}$ Był nim do 1890 r. M. G 1 iń s k i, Ludzie dziewiętnastowiecznego Gdańska, Gdańsk 1994, s. 36 .

${ }^{38}$ Tamże, s. 61-62.

${ }^{39}$ R. Freytag, Die Existenzfrage des Kunstbaues des ehemaligen Franziskanerkloster zu Danzig und des darin vorhandenen vaterländischen Museums, vol. 1-2, Danzig 1863, s. 64; F. A. B r a n d s t ät e r, Das Franziskanerkloster und das Danziger Museum, w: Der Neuen Preussischen Provizial-Blätter, red. A. Hagen, Bd. 9, Köningsberg 1856, s. 305-313; J. A. L i c h t, Die Wiederherstellung des ehemaligen Franziskanerklosters in Danzig, Notizheft des Westpreussischen Architekten-und Ingenieur-Vereins, Danzig 1877; T. P i a s k o w s k i, Dzieje przebudowy średniowiecznego klasztoru pofranciszkańskiego na siedzibę pierwszego muzeum w Gdańsku, „Jantarowe Szlaki“, 37 (1994) z. 3, s. 24-27.

${ }^{40}$ APG, sygn. APG 361/235, s. 1-17; sygn. APG 361/160; R. F r e y t a g, Estrehlke, Verzeichnis der die heidmischen Alterhümer enhaltenche Abtheilung des Museums zu Danzig, w: Der Neuen Preussischen Provinzial-Bläter, red. A. Hagen, Königsberg 1856, s. 269-278; Cz. B e te l e j e w s k a, Muzeum Miejskie w Gdańsku, s. 14-15.

${ }^{41}$ T. P i a s k ow s k i, Dzieje przebudowy, s. 27. 
kowania pomieszczeń na cele wystawiennicze towarzystwa ${ }^{42}$. Muzeum organizowało ekspozycje i wypożyczało także dzieła na wystawy do Berlina i Królewca. Co roku od 1897 odbywała się jedna czasowa wystawa określana w dokumentach jako nadzwyczajna ${ }^{43}$.

Należy dodać, że w budynku dawnego klasztoru od r. 1881 pokazywało również swoje zbiory Westpreussische Provinzial und Kunstgewerbemuseum ${ }^{44}$. W 1884 r. rzeźby i meble z tego muzeum zostały dołączone do zbiorów Stadtmuseum.

Po Rudolfie Freitagu kolejnymi kustoszami muzeum byli: Luis Sy (18151887), od 1888 r. Wilhelm August Stryowski (1834-1917) ${ }^{45}$, a od 1912 r. dr Hans Friedrich Secker, pełniący wcześniej w Stadtmuseum funkcję konserwatora, doskonale wykształcony historyk sztuki ${ }^{46}$, który następnie był dyrektorem kolońskiego Wallraf-Richartz-Museums. To on wystąpił do magistratu z propozycją nowej organizacji muzeum i zmian w sposobie ekspozycji, które nie odpowiadały ówczesnym wymogom muzealnictwa ${ }^{47}$. Zauważył i podkreślił duże zaniedbania w stanie technicznym budynku, przeciekający dach, nieusuwalny kurz w pomieszczeniach wystawowych, brak możliwości wietrzenia i zły stan bezpieczeństwa zbiorów $^{48}$. Okazało się, że kradzieże eksponatów były na porządku dziennym ${ }^{49}$. Zwiedzający posuwali się nawet do zdejmowania obrazów ze ścian. Uszkadzali obrazy o treści erotycznej, młodzież przychodziła do muzeum na randki, a robotnice $\mathrm{w}$ fartuchach fabrycznych, by spokojnie zjeść śniadanie. Nadzór nad eks-

${ }^{42}$ Archiwum Muzeum Narodowego w Gdańsku, rkps A/I/3, Zur Geschichte des ehemaligen Franziskaner Klosters, s. 107-109.

${ }^{43}$ Berichte des Magistrats der Stadt Danzig über den Stand der dortigen Gemeidcangelegenheiten bei Ablauf des Verwaltungsjahres od roku 1891 do 1897, wydawane przez Stadtmuseum Danzig. Cz. B e t l e j e w s k a, Muzeum Miejskie w Gdańsku, s. 19-21, 22.

${ }^{44}$ B. W ł o d a r s k a, Cyna. Katalog zbiorów Muzeum Narodowego w Gdańsku, Gdańsk 1975; T. G r z y b k o w s k a, Gdańskie Muzea, s. 34; Cz. B e t 1 e j e w s k a, Kolekcja mebli Muzeum Narodowego w Gdańsku, „, Jantarowe Szlaki”, 37 (1994) nr 3 (233) s. 52.

${ }^{45}$ A. R. Chodyń sk i, Malarz gdański-Wilhelm August Stryowski (1834-1917), „Rocznik Gdański”, 36 (1976) s. 137-159.

${ }^{46}$ Napisał m. in.: Das Danziger Uphagenhaus. Sonderdruck aus der Zeitschrift Dekorative Kunst. b. d wyd i m., 1903; Führer durch die öffentlichen Kunstsammlungen in Danzig, Bd 1. Die Städtische Gemäldegalerie im Franziskanerkloster (Stadtmuseum), Danzig 1913; Die Kunstsammlungen im Franziskanerkloster zu Danzig, Berlin 1917; Die alte Töpferkunst Danzigs und seiner Nachbarstädte. Sonderdruck aus der Cicerone, Jahrgang VII, 1915. Leipzig, 1915; Die Galerie Der Neuzeit im Museum Wallraf - Richartz. Herausgegeben v.d. Wallraf-Richartz-Gesellschaft in Köln1927 ; Ein Beispiel für den Stilwandel bei Dürer, „Bildende Kunst“, 3 (1955).

${ }^{47}$ Denkschrift zur Neuorganisation der Danziger Kunstsammlungen I. Gemäldegalerie, 1 October 1912, s. 1-31. APGd., sygn. APG 361/235

${ }^{48}$ Cz. B e t 1 e j e w s k a, Muzeum Miejskie w Gdańsku, s. 24. APG., sygn. APG 361/235.

${ }^{49}$ Kradzież taka zdarzyła się 12 lipca 1908 r. Ukradziono wtedy obraz o niewielkich wymiarach autorstwa nieznanego niderlandzkiego malarza. H. K o w a $1 \mathrm{~s} \mathrm{k} \mathrm{a,} \mathrm{Pastor} \mathrm{Adolf} \mathrm{Mundt} \mathrm{z} \mathrm{Kieżmarku}$ i dzieje jego kolekcji, w: Z dziejów kultury Pomorza XVIII-XX wieku, red. J. Borzyszkowski, C. Obracht-Prądzyński, t. 2, Gdańsk 2004, s. 32. 
pozycją pełniło trzech inwalidów w wieku od 75 do 88 lat. Dlatego w swoim raporcie Secker apelował do magistratu o zatrudnienie sprawnych pracowników ochrony. Wycenił niezbędne prace remontowe, administracyjne i fundusze na zakupy potrzebne do dalszego funkcjonowania muzeum. Secker dokonał przewartościowania zbiorów, nowej ich systematyzacji. W myśl nowych wymogów i potrzeb stworzył na przełomie 1912 i 1913 r. w wyremontowanych salach ekspozycję muzealną opartą na ich rzeczywistej wartości historycznej i artystycznej. Przykładał dużą wagę do zapewnienia obrazom odpowiedniego w tonacji tła ścian. Pouczające są jego opisy sal ekspozycyjnych, a szczególnie umiejętność wykorzystania klasztornych wnętrz do ekspozycji sztuki sakralnej. Była ona pomieszczona we wnętrzu małego refektarza. Na żebrach sklepień królowała czerwień, złoto i błękit, a na ścianach róż. Pola zaś sklepień były pomalowane na biało. Na parterze znajdowały się płyty przedprożowe, późnogotyckie drzwi, meble, odlewy rzeźb antycznych, wyroby z bursztynu pokazywane na tle barokowych obrazów i mebli, na pierwszym piętrze wyroby ceramiczne, złotnictwo oraz meblarstwo. Były także rekonstrukcje wnętrza kamienicy mieszczańskiej i gdańskiej sieni. Wystawione dzieła zyskały etykiety poszerzone o objaśnienia treści obrazów, właścicieli. Opracował również przewodniki po ekspozycji i wygłaszał odczyty na temat malarstwa niderlandzkiego oraz wypowiadał się w sprawach zabytkoznawstwa, konserwatorstwa i muzealnictwa ${ }^{50}$. Za wysokiej jakości uznał zbiory malarstwa niderlandzkiego, pochodzące w znacznej mierze z kabrunowskiej kolekcji oraz zbiory malarstwa europejskiego. Biorąc pod uwagę przeszłość Gdańska o chlubnych tradycjach artystycznych powyjmował z magazynów dzieła malarstwa dawnego i zabiegał o ich konserwację oraz zakupienie odpowiednich do ich eksponowania ram przypominających ramy z epoki ich powstania. Środki na konserwację niderlandzkich obrazów dało gdańskie kupiectwo, a na remont pomieszczeń miasto. Secker sporządził także spis obrazów, który opatrzył znakami wartości. Z uwagi na profil muzeum miejskiego uważał, że malarstwu gdańskiemu należy poświęcić jak najwięcej uwagi, przeznaczając na jego ekspozycję trzy sale wystawowe, w których znajdą się portrety najwybitniejszych Gdańszczan, gabloty z rysunkami Andreasa Stecha, Daniela Chodowieckiego, Jacoba Wessla i Daniela Schultza. Wprowadził także oddzielną wystawę malarstwa końca XIX i pocz. XX w. Uważał, że największe preferencje należą się sztuce gdańskiej, którą trzeba gromadzić i opracowywać. Niektóre z obrazów oddał szkołom do dekoracji pomieszczeń, a wątpliwej wartości depozyty właścicielom. Miał też swoje zdanie w sprawie gromadzenia rzemiosła artystycznego i potrzeby stworzenia nowego stylu w rzemiośle artystycznym. Dokonany przez dra Seckera przewrót, $\mathrm{w}$ dobrym tego słowa znaczeniu, $\mathrm{z}$ wyraźnie nakreślonym programem gromadzenia, nowe aranżacje i systematyzacja zbiorów połączona z próbą ich nowych atrybucji budziła zachwyt władz miasta i znawców oraz samych zwiedzających ${ }^{51}$.

${ }^{50}$ H. F. S e c k e r, Öffentliche und private Kunstpflege, w: Danziger Neueste Nachrichten, 1913, nr 164.

${ }^{51}$ P. A b r a m o w s k i, Die Neugestaltung der Danziger Kunstsammlungen, „Museumskunde“, 1915, Bd. 11, Heft 4, s. 173-182. 
Planowano rozbudowę muzeum od strony południowej o Kunshalle oraz dodatkowo budynek Muzeum Przyrodniczego w duchu uniwersalizmu. Wykonanie tych planów uniemożliwił wybuch pierwszej wojny światowej. Po powołaniu Seckera do Kolonii na dyrektora Wallraf-Richartz-Museums na stanowisku nowego dyrektora Stadtmuseum pojawił się w 1921 r. Walter Mannowsky, późniejszy specjalista od tkanin i rzemiosła artystycznego, a od 1938 r. dyrektor Muzeum Rzemiosł Artystycznych we Frankfurcie nad Menem ${ }^{52}$. On to przyczynił się do dalszej przebudowy gdańskiego muzeum, zwiększenia liczby personelu, zmian ekspozycyjnych. To właśnie wtedy wykorzystując klasztorny, średniowieczny urok pomieszczeń przy krużganku wschodnim zorganizował wystawę plastyki z wieków XIV-XV. Muzeum posiadało pokaźny zbiór rzeźb kamiennych i drewnianych $\mathrm{z}$ terenu Pomorza Wschodniego, a główny właśnie zrąb stanowiły rzeźby z okresu średniowiecza ${ }^{53}$. Wystawy organizowano częściej niż dotychczas, ale nowe zakupy obiektów do muzeum były w tym czasie skromne. Złożyła się na to sytuacja uwarunkowana światowym wielkim kryzysem ekonomicznym. Jednak na uwagę zasługują zakupy 71 dzieł graficznych dobrej klasy (artystów od XVII po XX w.), obrazu A. Möllera Pięć zmystów, Portretu proboszcza Gnospiusa, pracy Schulza i wielu mebli z licytacji kolekcji Basnera w Sopocie w $1929 \mathrm{r}^{54}$. Podczas dyrektorowania Mannowskiego zaczął pracę w muzeum Willi Drost (1892-1964) i z cza sem objął stanowisko dyrektora. Drost, historyk sztuki, autor książek o sztuce gdańskiej oraz inwentaryzacji gdańskich kościołów, związany był do czasu przyjazdu do Gdańska z Uniwersytetem w Królewcu. Z nazwiskiem tego dyrektora łączą się trudne lata egzystencji muzeum podczas wojny i zaraz po niej. Dyrektor Drost razem z miejskim konserwatorem zabytków Erichem Volmarem zostali w Gdańsku i współpracowali z Polakami przejmującymi muzeum (prof. Janem Kilarskim i Stanisławem Turskim).

W latach 30. XX w. muzealne zasoby zasiliła spora ilość nabytków dla działu rzemiosła artystycznego, rzeźby i grafiki. Godnym podkreślenia jest fakt, że w latach poprzedzających wybuch drugiej wojny światowej Stadtmuseum współpracowało z gdańskimi kościołami. Było też odpowiedzialne za prace związane z ochroną dóbr kultury w Gdańsku i inwentaryzację zabytków ruchomych w kościołach. Zinwentaryzowano więc paramenty liturgiczne z kościoła NMP. Przeprowadzano konserwację rzeźb i plastyki gotyckiej, np. Piety z Pręgowa (1420 r.), epitafium z kościoła św. Katarzyny (1595 r.), ale także wykonano prace przy ołtarzach w kościołach w Helu i Barwicach. Podjęto się też prac nad inwentaryzacją malarstwa i założono w tym celu archiwum fotograficzne ${ }^{55}$.

Już w 1938 r. podjęto prace przy zabezpieczeniu zbiorów na wypadek wojny. Zlikwidowano wówczas wszystkie wystawy stałe, a obiekty przeniesiono na

${ }^{52}$ M. A n d r z e j e w s k i, Ludzie wolnego miasta Gdańska (1920-1939), Gdańsk 1997, s. 72.

${ }^{53}$ D. K a c z m a r z y k, Straty wojenne Polski w dziedzinie rzeźby, Warszawa 1958.

${ }^{54}$ E. B a ry l ew s ka-S z y mań s ka, W. S z y mań s ki, Friedrich Basner, szkic biografii kolekcjonera, w: Teki Gdańskie, t. 3, Gdańsk 2001.

${ }^{55} \mathrm{Cz}$. B e t 1 e j e w s k a, Muzeum Miejskie w Gdańsku, s. 29-30. 
parter. Natomiast w kwietniu 1940 r. otwarto muzeum na nowo i zorganizowano odbudowaną ekspozycję. Lata 1940-1945 stanowią najmniej zbadany okres funkcjonowania muzeum. Wiadomo jednak, że na przełomie 1940 i 1941 r. zakupił dużą partię obrazów dla muzeum Gauleiter Forster ${ }^{56}$. Niepewna sytuacja i zmiana losów wojny przesądziła o podjęciu akcji dokonywania spisów ewakuacyjnych. Mimo poszukiwań nie dysponujemy jednak pełnymi spisami. Do dzisiaj nie odnaleziono ksiąg inwentarzowych muzealiów. Archiwum i biblioteka muzeum, gromadzona dokumentacja fotograficzna również uległy częściowemu rozproszeniu. Zbiory zostały ewakuowane. Najcenniejsze malowidła wywieziono do Rzeszy, inne dzieła albo umieszczono w miejscowościach leżących blisko Gdańska albo znaleziono dla nich lokum w różnych punktach miasta. Jednym z ostatnich miejsc zwożenia niektórych muzealiów były piwnice Zbrojowni ${ }^{57}$. Część obiektów pozostawionych w muzealnym gmachu uległa zniszczeniu podczas pożaru. Po wkroczeniu Rosjan do miasta, a następnie po ustaniu działań zbrojnych i odnalezieniu ukrytych dzieł, wywieziono je jako trofeum wojenne do Związku Radzieckiego ${ }^{58}$. Dopiero w 1956 r. w ramach akcji rewindykacyjnej część z nich powróciła ${ }^{59}$. Inne niestety pozostają tam nadal. Do gdańskiego muzeum po wojnie trafiła również niewielka część z wywiezionej z Waplewa kolekcji hrabiów Sierakowskich. W 1945 r. stanowisko dyrektora muzeum objął Jan Chranicki (1906-1976). Pod jego kierownictwem w latach 1945-1947 sporządzono nowy Inwentarz Muzeum Miejskiego ${ }^{60}$. Żadna muzealna przedwojenna kolekcja nie ocalała w całości ${ }^{61}$ Straty poniesione podczas wojny były ogromne. Do dzisiejszego dnia podejmowane są wysiłki dotyczące oszacowania ich wielkości i zasięgu ${ }^{62}$.

Zniszczony pożarem w 1945 r. gmach odbudowano do 1956 r., a pierwszą

${ }^{56}$ Wiadomość tę zawdzięczam Helenie Kowalskiej, która przygotowuje artykuł Zbiory Gauleitera Forstera w Stadtmuseum w Gdańsku. Pogląd jaka była ich zawartość daje opublikowany w 1943 r. przez Willi Drost, Die Danzieger Gemäldegalerie. Neuewerbungen 1940/41, Danzig 1943.

${ }^{57}$ Inventar der Kunstgegenstände des Danziger Stadtmuseums Ende Juli 1945 von Prof. Dr W. Drost, Abteilung I Malerei, Ml, sygn. MNG/A/I/14, s. 1-35.

${ }^{58}$ M. S t r y c z y ń s k i, Gdańsk w latach 1945-1958. Odbudowa organizmu miejskiego, Gdańsk 1981, s. 32-46.

${ }^{59} \mathrm{~K}$. W. M i t a r e w a, Wystawa dzieł zabezpieczonych przez ZSRR, Gdańsk 1956.

${ }^{60}$ Archiwum MNG/A/I/20 (wiadomości o sprawach związanych z ewakuacją i powojenną historią muzeum udostępnione przez H. Kowalską).

${ }^{61} \mathrm{~K}$. Gó r e c k a - P e tra j t i s, Zbiory malarstwa dawnego $w$ Muzeum Narodowym w Gdańsku - historia i współczesność, ,Jantarowe szlaki”, 37 (1994) nr 3 (233), s. 35-39; G. Z i n ó w k o, K. Z a bu ska, Rysunki i grafiki z kolekcji Jakuba Kabruna w zbiorach Muzeum Narodowego w Gdańsku, s. 41-43; M. G ó r a 1 s k a, Artyści Gdańscy XIX wieku, s. 43-46; B. S z t y b e r, Brygitki gdańskie i ich działalność hafciarska w końcu XV wieku, s. 47-50; Cz. B e t 1 e j e w s k a, Kolekcja mebli Muzeum Narodowego w Gdańsku, s. 51-52.

${ }^{62}$ W. To m k i e w i c z, Katalog obrazów wywiezionych z Polski przez okupantów niemieckich w latach 1939-1945, Malarstwo obce, Warszawa 1949; Europejskie dziedzictwo rozproszone, Gdańsk 1992, (wyd. 2, Gdańsk 1993); M. R o m a n o w s k a - Z a d r o ż n y, Straty wojenne. malarstwo obce, t. 1, Poznań 2000; M. K o r z o n, Przyczynek do historii gdańskich zbiorów artystycznych, 
ekspozycję udostępniono 30 maja 1948 r.. Sukcesem cieszyła się urządzona przez Jana Chranickiego w krużgankach wystawa przybliżająca wygląd domu patrycjusza gdańskiego. Pokazano na niej dzieła rzemiosła artystycznego, wytwory konwisarstwa $^{63}$ i kowalstwa, meble flamandzkie, holenderskie, gdańskie (XIV-XIX wieku $)^{64}$, arcydzieła złotnictwa gdańskiego, rzeźbę średniowieczną i renesansową.

Szczególnie dobrze wykorzystano mistyczny nastrój tworzony przez klasztorne wnętrza, urządzając galerię rzeźby średniowiecznej. W latach pięćdziesiątych XX w. uczestnicy wycieczek przyjeżdżających z małych wsi do muzeum klękali przed Pietą wystawioną w kapitularzu. Wystawa w krużgankach do dnia dzisiejszego zachowała w znaczącym stopniu koncepcję pierwotnej aranżacji.

Świetnie pokazane na parterze budynku w ciemnym wnętrzu, małego gotyckiego skarbca klasztornego, są również przedmioty z cyny o angielskich wpływach. Większa część z nich należała dawniej do kolekcji Ludwika Garbego ${ }^{65}$. Każda z galerii muzealnych została tak zorganizowana, by dopasować się do wnętrza, jego specyfiki i wyzyskać nastrój, który zapewnia historyczny gmach klasztoru $^{66}$. Ekspozycję zabytkowych sreber stworzono w małym refektarzu ${ }^{67}$. Spośród eksponatów unikatowym jest złocona kadzielnica w formie statku oraz wczesne monstrancje XV wieczne, liturgiczne naczynia protestanckie, a także kufle, puchary poczęstne zwane wilkomami oraz oprawy książkowe. Wśród znanych twórców wymieńmy Jacoba Beckhausena, Nathaniela Schlaubitza, Beniamina Berenta I, Christiana Pichgiela. W sali wielkiej refektarza eksponowana jest od 1982 r. ceramika dawna, obejmująca ok. 850 obiektów, podzielonych według typów (kamionka, ${ }^{68}$ fajans, porcelana, wyroby garncarskie), prezentowanych zgodnie z proweniencją ${ }^{69}$. W sklepionej sali znaleźć można majoliki włoskie i hiszpańskie, fajanse z Delft, Niemiec, Anglii, ceramikę z Francji, flizy kafelkowe z Holandii, piece XVIII wieczne, porcelanowe wyroby z Chin i Japonii, porcelanę ze słynnych manufaktur europejskich Berlina, Miśni, Sevre oraz manufaktur polskich. Są też fajanse produkowane w Gdańsku ${ }^{70}$.

„Cenne, Bezcenne, Utracone”, 2000, nr 1 (19), nr 2 (20), nr 3 (21); A. K o zł o w s k a, Czy nasze obrazy wróca z Rosji?, „Gazeta Wyborcza”, dodatek Trójmiasto, 28 I 2005, s. 4; K. G ó r e c k a P e tr a j t i s, Straty wojenne w zbiorach malarstwa muzeum Miejskiego w Gdańsku (Stadtmuseum), w: Straty wojenne Muzeum Miejskiego w Gdańsku. Straty w dziedzinie sztuki, malarstwa, rysunku, grafiki, rzeźby, t.1, Gdańsk 2005, s. 35-41.

${ }^{63}$ B. T u c hołk a - W ł o d a r s k a, Cyna od XV do XIX w. Katalog stałej wystawy ze zbiorów Muzeum Narodowego w Gdańsku, Gdańsk 1992.

${ }^{64} \mathrm{Cz}$. B e t 1 e j e w s k a, Meble gdańskie.

${ }^{65}$ Tu chołka - W łod a rs ka, Cyna od XV do XIX w., s. 5

${ }^{66}$ T. Gr z y b k o w s k a, Muzea Gdańska, Gdańsk 1996, s. 15-74.

${ }^{67} \mathrm{~B}$. T u c h ołk a - W ł o d a r s k a, Goldschmiedekunst vom 14. bis zum 20. Jahrhundert in den Sammlungen des Nationalmuseums in Gdańsk, Gdańsk 2005.

${ }^{68}$ E. K i l a r s k a, Kamionka. Katalog zbioru, Gdańsk 1991.

${ }^{69}$ E. Kila r ska, Ceramika w zbiorach Muzeum Narodowego w Gdańsku, Przewodnik po wystawie, Gdańsk 1984.

${ }^{70}$ Tamże. 
Sale pierwszego i drugiego piętra zajmuje ekspozycja malarstwa dawnego. W południowym skrzydle pokazywane jest malarstwo niderlandzkie (XV-XVIII wieku), które otwiera w oddzielnej sali umieszczony w szklanej kapsule tryptyk Sad Ostateczny Hansa Memlinga z XV w., który od 1473 r. znajdował się w kościele NMP w Gdańsku a po drugiej wojnie światowej został wywieziony do Ermitażu by powrócić w 1956 r. Dalsze sale zajmuje malarstwo gdańskie od XVI do XIX w. ${ }^{71}$ i malarstwo polskie od XIX do poł. XX w. Sale drugiego piętra przeznaczone są na ekspozycje malarstwa niemieckiego XIX w. ${ }^{72}$ i wystawy czasowe. Jednak w części z nich pokazano meble gdańskie i elbląsko-żuławskie z XVIII w. oraz zegary, jako że Gdańsk był ośrodkiem zegarmistrzostwa w XVII i XVIII w. ${ }^{73}$

Wiodącym działem jest dział malarstwa gdańskiego, a wśród zgromadzonych tam obrazów cenne są prace Antona Möllera twórcy wielu luterańskich moralitetów, Andreasa Stecha, pracującego pod wpływem malarstwa flamandzkiego, Hermana Hana, Daniela Schultza oraz Jacoba Wessla. Na uwagę zasługują obrazy przedstawicieli rodziny Meyerheimów, Michaela Gregoroviusa, Jan Karla Schultza, Alberta Juchanowitza, Luisa Corintha, Wilhelma Stryowskiego.

Należy jednak zwrócić uwagę, że część galerii rzeźby średniowiecznej jak i malarstwa gdańskiego jest zbudowana $z$ obrazów religijnych, pochodzących z kościołów gdańskich lub będących ich depozytami. W latach 90 ubiegłego wieku, zwrócono znaczną część obrazów tablicowych i rzeźb. Były także sytuacje, gdy radzono sobie inaczej np. oddając do kościoła kopię, jak w przypadku epitafium rodziny Henningów z kościoła św. Katarzyny w Gdańsku.

Galeria malarstwaniderlandzkiego ${ }^{74}$ natomiastjestjednązlepiej wyposażonych w Polsce, wśród dzieł znaczących znajdziemy tu obrazy Paula Vredemana de Vriesa, Jana van Goyena, Pietera Brueghela Młodzszego, Isaaka van Ostade, Davida Teniersa Młodszego, Petera Lastmana, Jacoba Jordaensa, Simona Luttichuysa, Alberta Cuypa, Isaka Swanenburga, Pietera de Hoocha, Nicolaesa Maesa.

Muzeum posiada interesujący zbiór tkanin ${ }^{75}$ oraz jedną z wyżej ocenianych w Europie kolekcji rysunku i grafiki ${ }^{76}$. Prace są eksponowane na znaczących wystawach w kraju i za granicą. Na co dzień nie mają stałej galerii, gdyż czas ich prezentacji jest z powodów konserwatorskich ograniczony. Wynika to z techniki

${ }^{71}$ M. G ó r a 1 s k a, L. H y s s, Danziger Malerei des 19. Jahrhunderts, Münster 2005.

${ }^{72}$ M. G ó ra 1 s k a, Artyści gdańscy XIX wieku, s. 43-46.

${ }^{73}$ Cz. B e t l e j e w s k a, Kolekcja mebli Muzeum Narodowego w Gdańsku, s.51-52.

${ }^{74} \mathrm{~K}$. Gó r e c k a - P e traj t is, Malarstwo flamandzkie i holenderskie XVII wieku w zbiorach Muzeum Narodowego w Gdańsku, Przewodnik po wystawie, Gdańsk 1993.

75 „Zeszyty Muzeum Pomorskiego w Gdańsku”, 1969, s. 7-9; M. Ż e le w s k a, Gdański zbiór tkanin i haftów średniowiecznych. Muzeum Pomorskie w Gdańsku, Gdańsk 1966; B. S z ty b e r, Tkaniny i hafty, w: Aurea Porta Rzeczypospolitej. Sztuka Gdańska od pot. XV do końca XVII w., red. T. Grzybkowska, s. 329-340.

${ }^{76}$ G. Z i n ó w k o, Najcenniejsze rysunki europejskie ze zbioru Muzeum Narodowego w Gdańsku, Gdańsk 1990; K. Z a b u s k a, Rysunki i grafiki z kolekcji Jakuba Kabruna w zbiorach Muzeum Narodowego w Gdańsku, s. 40-43. 
wykonania i kruchości papieru. Wśród nazwisk artystów zgromadzonych prac graficznych wymieńmy tylko Dürera, Cranacha Starszego, Aldorfera, Marcantonio Raimondiego, Guido Reniego, Jacquesa Callota, Rembrandta, Lucasa z Leydy, Jacoba Jordaensa, Egidiusa i Jana Sadelera, Hendricka Goltziusa. Wśród prac rysunkowych przeważają szkoły niemieckie (Albrecht Dürer, Manuel Deutsch, Hans Holbein), ale także rysunki Goltziusa, Sprangera, Bloemaerta, Carla van Mandera, Pietro da Cortona, Guercino, Rembrandta i jego ucznia Samuela van Hoogstratena W 1937 r. muzeum przejęło jako depozyt stały bogatą kolekcję paramentów liturgicznych z kościoła mariackiego. Były to głównie haftowane gotyckie i renesansowe ornaty oraz tkaniny wywiezione podczas wojny w okolice Halle, które częściowo wróciły do Gdańska w $1961 \mathrm{r}^{77}$.

W pierwszych powojennych latach muzeum przyjmowało obrazy ze składnicy konserwatorskiej w Oliwie. Większą część z nich stanowiły obiekty ocalałe ze zrujnowanych kościołów Gdańska i z terenu województwa gdańskiego. Najczęściej były to obrazy epitafijne, ołtarzowe, rzeźby, ale także wyposażenie wnętrz z Ratusza Głównomiejskiego, Domu Uphagena w Gdańsku, Dworu Artusa. Z czasem dzieła te powróciły w miejsce swego przeznaczenia. Muzeum odegrało więc rolę miejsca zabezpieczenia a jednocześnie właściwej ich prezentacji. Powojenna historia działania muzeum to również wysiłki nad pomnożeniem zbiorów, dokonywanie zakupów, ale także zabezpieczanie dzieł sztuki odnalezionych w terenie i przekazy z Urzędu Bezpieczeństwa Publicznego. Od lat 60 XX w. kupowano także eksponaty o wysokiej wartości artystycznej, gromadząc je już w przemyślany sposób. Zbiory w tym czasie powiększały się także o depozyty i darowizny od osób prywatnych i instytucji. Wysokie ceny dzieł sztuki obecnie przy skromnym budżecie muzeum, nie pozwalają na częste zakupy. Podstawową formą działalności muzeum jest umożliwienie szerokim kręgom społeczeństwa kontaktu ze sztuką, organizowanie wystaw i przybliżanie wiedzy na tematy związane ze sztuką polską, ale przede wszystkim ilustrujące dorobek artystyczny Gdańska i ośrodków północnoeuropejskich. Muzeum prowadzi wymianę z muzeami polskimi i zagranicznymi oraz wydaje własny rocznik, ukazujący się od 1976 r. „Gdańskie Studia Muzealne”78. W marcu 1999 r. została otwarta wystawa Pelplin dla Gdańska-Gdańsk dla Pelplina, która była wydarzeniem inicjującym powojenną współpracę gdańskiego muzeum z instytucją kościelną. Na 90 lat został przekazany do muzeum depozyt ze skarbca bazyliki katedralnej w Pelplinie. Depozyt ten to paramenty liturgiczne, insygnia, szaty liturgiczne, dzieła sztuki hafciarskiej i włókienniczej oraz krawiectwa, obejmujący okres od XVII do początków XX w ${ }^{79}$. Na swoim koncie muzeum od końca lat $90 \mathrm{XX}$ w. ma wiele uda-

${ }^{77}$ Informator Muzeum Pomorskiego w Gdańsku, Gdańsk 1968, s. 2; M. Ż e 1 e w s k a, Ornat z gdańskiego warsztatu Brygidek, Gdańsk 1989.

${ }^{78}$ wcześniej wydawano „Zeszyty Muzeum Pomorskiego w Gdańsku” a od 1973 r. „Zeszyty Muzeum Narodowego w Gdańsku”.

${ }^{79}$ Pelplin dla Gdańska - Gdańsk dla Pelplina. Katalog wystawy. Marzec 1999, red. B. Sztyber, Gdańsk 1999. 
nych wystaw m. innymi monumentalną ekspozycję podkreślającą kulturotwórczą rolę Gdańska, Aurea Porta Rzeczypospolitej ${ }^{80}$.

W trakcie działalności Muzeum Narodowe rozrastało się i przybywały nowe oddziały. W 1970 r. w Pałacu Opatów w Gdańsku Oliwie powstał Dział Sztuki Współczesnej, który pierwszą stałą ekspozycję zaprezentował w 1979 r. Dział ten gromadzi i wystawia eksponaty związane ze sztuką Wybrzeża i sztuką polską ${ }^{81}$. Trzon ekspozycji stanowi malarstwo, uzupełnione przykładami rzeźby i ceramiki, prezentującymi najważniejsze postawy twórcze. Na uwagę zasługuje również mieszczący się w Pałacu Opatów dział teatralny istniejący od $1976 \mathrm{r}$. i powstały z inicjatywy Gdańskiego Oddziału Stowarzyszenia Polskich Artystów Teatru i Filmu oraz Sekcji Scenografów Związku Polskich Artystów Plastyków. Jest to obok placówki w Katowicach, jedyne Muzeum Narodowe zajmujące się dokumentowaniem, ochroną i udostępnianiem tak łatwo zniszczalnej i delikatnej materii, jaką jest historia teatru i historia scenografii w Polsce. Do cennych materiałów gromadzonych przez muzeum należą dokumenty pracy teatralnej, portrety aktorów, projekty scenograficzne i projekty kostiumów, makiety, kostiumy teatralne programy, afisze i plakaty teatralne, fotografie ze spektakli, prób i premier, fotogramy, egzemplarze reżyserskie i scenariusze, wydawnictwa teatralne oraz dokumentacja związana z sylwetkami reżyserów, aktorów, scenografów. Do głównych zagadnień opracowywanych należy prezentacja historii teatralnej Wybrzeża i teatrów polskich wraz ze współczesną polską plastyką teatralną. Początkowo wystawy organizowane przez ten dział miały charakter wystaw czasowych, a od 2001 r. utworzona została w Pałacu Opatów w Oliwie odrębna Galeria Teatralna.

Natomiast w zabytkowym Spichrzu XVIII-wiecznym, sąsiadującym z pałacem w 1988 r. utworzono Oddział Etnografii ${ }^{82}$. Muzeum Narodowe w Gdańsku posiada jeszcze jeden oddział. Jest nim od 1978 r. Muzeum Hymnu Narodowego w Będominie. Od 1995 r. działa przy Muzeum Gdańska Galeria Fotografii. Najmłodszym oddziałem muzeum jest Zielona Brama, w której od 1880 r. mieściło się Zachodniopruskie Muzeum Prowincjonalne. W 2002 r. Zielona Brama została udostępniona dla zwiedzających, a w 2004 r. przekazana dla Muzeum Narodowego przez samorząd województwa w nawiązaniu do tradycji kulturalnych i muzealnych, jakie pełnił ten budynek w przeszłości (w latach 1746-1829 jako siedziba Towarzystwa Przyrodników, w latach 1835-1872 odbywały się tam wystawy urządzane przez Gdańskie Towarzystwo Przyjaciół Sztuki). Obecnie przygotowywane są tam wystawy czasowe. Często gmach Zielonej Bramy służy jako pomieszczenia reprezentacyjne dla władz miasta. Muzeum dba o swo-

${ }^{80}$ Aurea Porta Rzeczypospolitej. Sztuka Gdańska od pot. XV do końca XVII w., red. T. Grzybkowska, Gdańsk 1997.

${ }^{81}$ E. M u s z y ń s k a, Galeria polskiej sztuki współczesnej, Gdańsk 1983; J. B r a d tk e, Galeria wspótczesnej rzeźby gdańskiej w Parku Oliwskim, Gdańsk 1978; W. Z m o r z y ń s k i, Przewodnik po kolekcji polskiej sztuki współczesnej. Oddział Sztuki Współczesnej Muzeum Narodowego w Gdańsku, Gdańsk 2004.

${ }^{82}$ T. P r z ał a, Kultura ludowa Pomorza Gdańskiego, Gdańsk 1988, s. 3 
ich sponsorów, udostępniając ten gmach, jak również sale siedziby głównej na odczyty i imprezy dla firm i stowarzyszeń. Na koniec wypada odnotować kilka wydarzeń, które rozbudziły emocje, zresztą jak wiele rzeczy, które koncentrują się na sprawie własności i chęci posiadania.

W powojennych losach muzeum zdarzyła się kradzież w kwietniu $1974 \mathrm{r}$. Z ekspozycji muzealnej ukradziono dwa wysokiej klasy dzieła, obrazy Antonisa van Dycka Ukrzyżowanie i Kobieta niosaca żar Petera Brueghela Młodszego. Innym godnym odnotowania zdarzeniem w 1998 r. była decyzja wojewody Tomasza Sowińskiego, aby Muzeum Narodowe oddało kościołowi Mariackiemu Sąd Ostateczny Hansa Memlinga i pięć innych dzieł sztuki sakralnej ${ }^{83}$. Decyzja wstrząsnęła środowiskami związanymi ze sztuką. Polecenie wojewody nigdy nie zostało wykonane. Podzieliło tylko środowisko Gdańszczan na dwa obozy, a sprawa zabytków sztuki sakralnej rozproszonych po drugiej wojnie światowej uświadamia, że jest to problem ciągle jeszcze nie rozwiązany.

Sąd Ostateczny jest ciągle ozdobą Gdańska. Stracił on swą rolę jako obiekt kultu, jest dziełem sztuki. Dyrekcja muzeum uznała, że ten namalowany z dbałością o szczegóły obraz nie może być eksponowany w oddaleniu od widza. W gmachu muzeum przeznaczono dla niego oddzielną, kameralną salę, wygodną do oglądania. Tryptyk Memlinga spełnia ważną rolę na mapie zabytkowego dziedzictwa Gdańska, jest magnesem dla zwiedzających, gdyż siedziba muzeum leży daleko poza Głównym Miastem. Zapewnia też muzeum egzystencję i jest kartą przetargową dla sprowadzanych tu zagranicznych wystaw. Nie może podróżować jednak częściej niż co siedem lat. W rzeczywistości każde dzieło sztuki jest lokatą kapitału. Za wypożyczenie tryptyku do USA i Austrii muzeum gdańskie otrzymało obrazy impresjonistów francuskich oraz organizowało we współpracy z Muzeum Narodowym w Warszawie i Kunsthistorisches Museum w Wiedniu wystawę Transalpinum ${ }^{84}$.

Wieloletnie dzieje muzeum wpisanego w tradycję miasta i kompleks przestrzeni dawnego klasztoru oraz powrót po drugiej wojnie światowej franciszkanów do ich dawnej siedziby uświadomił, że dwie instytucje kultywujące kulturalną przeszłość stanowią dobre sąsiedztwo, a nawet mogą się nawzajem wspierać. Ale nim do tego doszło, pojawił się w związku z potrzebą budowy seminarium franciszkańskiego, problem odebrania dawnego klasztoru na te właśnie potrzeby i przeniesienia muzeum do innego budynku. Ten fakt nie przeszkodził jednak, by współpracować ze sobą. W 1995 r. dział teatralny przy współpracy OO. Franciszkanów, w prezbiterium kościoła Św. Trójcy w Gdańsku urządził wystawę Klisze pamięci. Labirynty Mariana Kołodzieja, a w 2001 r. - Zdarzyło mi się w Gdańsku. Szkicownik Starego Scenografa. Akt drugi z epilogiem - druga wystawa w prezbiterium kościoła Sw. Trójcy w Gdańsku dająca okazję do ponownego obcowania

${ }^{83}$ B. J a k u b o w s k a, Ostatnia bomba, „30 dni”, 15 (2000) z. 1, s. 34-39.

${ }^{84}$ Transalpinum. Od Giorgiona i Dürera do Tycjana i Rubensa. Dzieła malarstwa europejskiego ze zbiorów Kunsthistorisches Museum w Wiedniu, Muzeum Narodowego w Warszawie i Muzeum Narodowego w Gdańsku, red. D. Folga-Januszewska, A. Ziemba, Warszawa 2004. 
ze sztuką Kołodzieja, Honorowego Obywatela Miasta Gdańska i twórcy niezapomnianych ołtarzy papieskich z 1987 r. na Zaspie i sopockim hipodromie. Ekspozycja była poprzedzona wystawieniem przez Teatr „Wybrzeże” we wnętrzu franciszkańskiej świątyni sztuki Tragedia o bogaczu i Łazarzu Anonima Gdańskiego w reżyserii Krzysztofa Babickiego ze scenografią projektowaną przez Mariana Kołodzieja.

Te dwa wydarzenia spięły symboliczną klamrą przeszłość Muzeum i Kościoła. Były zarazem próbą przełamania lodów. W 2005 r. mimo licznych przeciwności, podjęto starania, aby nadal działać razem i wspierać się w intelektualnych wysiłkach i muzealniczych zamierzeniach, przy projektowaniu wystaw, organizowaniu sesji naukowych, koncertów, pokazów teatralnych i wspólnych przedsięwzięć związanych z życiem duchowym miasta i wrażliwością na różne rodzaje piękna. W pofranciszkańskim klasztorze mieściła się szkoła, która promieniowała daleko poza granice Rzeczpospolitej. Taka przeszłość zobowiązuje. Istnieje projekt połączenia przestrzeni wystawienniczej muzeum z przestrzenią kościoła Św. Trójcy. Te plany zainicjował list, podpisany w sierpniu 2005 r. przez Prowincjała Zakonu Braci Mniejszych Konwentualnych w Gdańsku o. Adama Kalinowskiego i Dyrektora Muzeum Narodowego w Gdańsku Wojciecha Bonisławskiego. W planach muzeum jest również rozbudowa przestrzeni wystawienniczej o przylegający do muzeum niezagospodarowany kwartał miejski, który umożliwiłby w tej części leżącego na uboczu głównych traktów turystycznych Dawnego Przedmieścia, zbudowanie $\mathrm{w}$ łączności z zespołem sakralnym i drzemiącym $\mathrm{w}$ nim potencjale duchowym przestrzeni kulturowej. Byłaby ona miejscem uświęconym nauką, sztuką i religią. Miejmy nadzieję, że tradycja, z której czerpie Muzeum Narodowe w Gdańsku pozwoli mu nadal gromadzić, chronić i udostępniać dzieła sztuki, a projekty zostaną zrealizowane. 